\title{
The Relationship Between Communication Practice and Organizational Performances in Organizations from Europe
}

\author{
Article history: \\ Received: 8 May 2014 \\ Sent for revision:18 June 2014 \\ Received in revised form:13 September 2014 \\ Accepted: 17 September 2014 \\ Available online: 1 November 2014
}

\begin{abstract}
The basic goal of the research in this paper was to explore the differences between private organizations in Europe regarding their organizational performances in the context of the existence and development of communication practices. The subject of the research was the analysis of communication practice and organizational performances in private organizations in 25 European countries. The methodology of the research included the exploration of the sample from the CRANET, an international human resource management (HRM) project in the period 2008-2010. The authors used statistical techniques to prove established hypotheses: descriptive statistics, chi square and t-test. The findings of the research pointed to the statistically significant differences between private companies that inform their employees about business strategy, financial results and organization of work regarding organizational performances. Also, there were presented trends of the usage of different communication techniques in countries of Europe. Private firms in Europe usually perform direct "upward" and verbal communication between managers and employees. Regarding the internalization of the business, authors found that companies operating mainly on international market usually inform their employees about strategy, finances and organization of work more than companies operating on local market.
\end{abstract}

Keywords: communication, performances, CRANET, Organization; Europe, Employees.

\footnotetext{
${ }^{1}$ University of Novi Sad, Faculty of Economics in Subotica

${ }^{2}$ University of Novi Sad, Faculty of Economics in Subotica, berber@ef.uns.ac.rs
} 
Leković B., Berber N.: The Relationship Between Communication Practice and...

\title{
Odnos između komunikacione prakse i organizacionih performansi u organizacijama iz Evrope
}

\begin{abstract}
Apstrakt: Osnovni cilj ovog istraživanja bio je utvrđivanje razlike između organizacija iz privatnog sektora iz Evrope u pogledu njihovih organizacionih performansi u kontekstu postojanja i razvoja komunikacije. Predmet istraživanja bila je analiza prakse komunikacije $i$ organizacionih performansi $u$ organizacijama iz privatnog sektora u 25 zemalja Evrope. Metodologija $u$ istraživanju obuhvatila je ispitivanje uzorka nastalog tokom projekta CRANET, međunarodnog projekta u oblasti menadžmenta ljudskih resursa, u period od 2008. do 2010. godine. Autori su koristili sledeće statističke tehnike kako bi ispitali postavljene hipoteze: deskriptivnu statistiku, Hi kvadrat test $i$ T-test. Rezultati istraživanja upućuju na postojanje statistički značajne razlike između organizacija it privatnog sektora, koje informišu svoje zaposlene o poslovnoj strategiji, finansijskim rezultatima $i$ organizaciji rada, u pogledu organizacionih performansi. Takođe, prikazani su trendovi u korišćenju različitih tehnika komunikacije u zemljama Evrope. Organizacije u privatnom vlasništvu $u$ Evropi obično koriste tehnike direktne uzlazne komunikacije $i$ verbalnu komunikaciju tokom procesa komuniciranja između menadžmenta organizacije i zaposlenih. U pogledu internacionalizacije poslovanja, autori su utvrdili da kompanije koje posluju na međunarodnom tržištu u većoj meri informišu svoje zaposlene o strategiji, rezultatima $i$ organizaciji rada nego organizacije koje posluju samo na lokalnom tržištu.
\end{abstract}

Ključne reči: komunikacija, performanse, CRANET, organizacija, Evropa, zaposleni.

\section{Introduction}

Communication is one of the most significant practices inside contemporary organizations and very important area of human resource management (HRM). It is defined as the process of transferring information from one person to another, through understandable symbols or signals. It is a way of mutual exchange of thoughts, ideas, wishes, desires, messages, through which human relationships are constantly evolving. Therefore, it is important to note that the communication process is the personal and social relation that includes personal and social dimension (Damnjanović et al., 2012, p. 112). Communication is a matter of each manager and employee in modern business, since the basic goal of the communication is the "provision, management, and understanding of information" (Leković, 2011, p. 190).

The basic goal of the research in this paper was to explore the differences between private organizations in Europe regarding their organizational 
Leković B., Berber N.: The Relationship Between Communication Practice and...

performances in the context of the existence and development of communication practices. The subject of the research was the analysis of communication practice and organizational performances in private organizations in several European countries. The methodology of the research included the exploration of the sample from the CRANET, an international HRM project in the period 2008/2010. For the purpose of this study authors used data for private companies in 25 European countries.

The research was presented in three parts. In the first part authors presented main theoretical views on communication possibilities in organizations. In the second part of the paper there have been presented methodology and data used for the exploration of the research hypotheses. In the third part authors presented the findings of the research and certain conclusions derived from statistical results.

\section{Literature review}

Communication, as a particularly important activity in each organization, is said to be the "heart" of effective human resources management. Authors Brewster, Sparrow and Vernon (2007) summarized views on the importance of communication in HRM and noted that effective communication may increase commitment, job satisfaction, be connector for the promotion and development of cooperation between organizational stakeholders, facilitate diffusion through teamwork, improve internal control and development of strategies. In the study of the Serbian banking sector Vemić-Đurković, Jotić and Marić (2013) found that better HRM practices, where communication is presented as an important indicator, possess more competitive workforce and better organizational performances.

In the field of communication, and in the line with the present research, it is especially interesting to explore forms of organizational communication. Depending on the relationship between the members of the communication process, there can be present formal and informal communication, direct or indirect, verbal and non-verbal, "upward" and "downward" communication.

The concept of direct communication was explored in terms of providing information to employees by managers, without an intermediary - a representative of employees (trade unions). Direct communication is typically seen as a key element of organizational strategy of including employees, covering a wide range of voluntary initiatives undertaken by employers that are designed to encourage active participation of workers in the (organizational) activities. The aim of these initiatives is to increase the level of commitment of employees in the organization. The initiatives may include some or all of the following: first, "increased information (flow) downward the 
Leković B., Berber N.: The Relationship Between Communication Practice and...

organization"; second, "increased information (flow) upward the organization"; third, changes in job design; fourth, financial involvement or participation; and, fifth, changes in leadership or management style towards a more participative approach. Also, direct communication is a central element in employee involvement. Direct communication may take different forms, be addressed to different categories of employees and cover different subjects. For example, it can be addressed to managers, professionals or clericals. It spans a number of different practices including briefing the workforce, quality circles, regular meetings with all or part of the workforce, suggestion schemes, appraisal interviews, newsletters and electronic communication (Croucher et al., 2006, p. 269). In this sense, it is also important that information can be a subject of the communication. Those can be information about regular, operative organization of work, or some information related to the financial results or of strategic importance. For example, authors from Turkey used the term direct communication to refer to briefing of non-managerial employees on issues related to business strategy and financial performance of the organizations (Tanova \& Nadiri, 2010).

Indirect communication, on the other hand, means that the flow of the communication process is performed trough a representative of employees and employers. This type of communication is characteristic for European companies. The employees in European countries may have more confidence in direct communication where the mechanism of collective bargaining is present. In other words, the creation of trade unions resulted in an increase of the staff confidence in their own ability to assess and respond to information obtained from management (Croucher et al., 2006, p. 273). The works council and union representation is a general characteristic of the European model of employment relations. Direct and indirect communications go hand in hand. Generally, according authors Tanova and Nadiri, "when an organization has increased indirect communication, they also have increased direct communication. In fact where there is a representative body such as unions that allow indirect communication, employees will also demand more direct communication from the employer" (Tanova \& Nadiri, 2010, p. 189).

\subsection{The Importance of the Communication in Contemporary Business and HRM}

For the purpose of the exploration of the importance of the communication in contemporary business, the authors analyzed several researches from the past. According to the authors from the Central and Eastern Europe (CEE) region, good communication with employees, labor relations and talent management are three most critical points observed by HR managers who participated in the research CEEIRT (Central and Eastern European International Research Team, http://www.ceeirt-hrm.eu/). In Serbian 
Leković B., Berber N.: The Relationship Between Communication Practice and...

companies these three activities were rated as most critical in the branches of the MNCs operating in the country (Poór et al., 2012, p. 49). Also, if we observe the entire region of Central and Eastern Europe, the communication took first place, slightly ahead of compensation and benefits, in terms of the critical issues of HRM (Poór et al., 2012, p. 46).

The importance of communication and connection between this process and HRM was highlighted by authors Den Hartog, Boon, Verburg and Croon (2013), who examined the managers' communication quality as a moderator of the relationship between manager-rated and employee-rated HR practice. The results of the research conducted in the Netherlands in 119 restaurants of the famous restaurant chain, where employees and line managers were involved, indicated that manager's clear, informative and useful communication is a key instrument for the effective implementation of HRM, and in the context of the studied firm the communication by managers may be even more crucial than the specific content of HR practices in affecting employee outcomes. Also, the management reports on the HRM practices are more positive than evaluations of employees on the same issue. This was interpreted in terms of reflecting the bias of managers, but also that there are different roles that managers and employees perform, their different possibilities to access the information on the expected HRM policies. Managers have a better insight into the use of HRM policies of the company, and they are the main filter for this information. Only when managers are able to communicate and carefully and understandably transfer this information, there can be expected to positively affect employee-rated HRM (Den Hartog et al., 2013, p. 1661). On the other hand, in the study by Brown, Ford, Spencer and Charlwood (2008) there have been found that if the upward communication allows greater autonomy and participation of employees in decision-making, then a positive impact can be expected on aspects of job satisfaction, which is one of very interesting and, above all, very important issues in both theoretical and practical HRM. Smidts, Pruyn, and Van Riel (2001) explored the impact of employee communication and perceived external prestige on organizational identification. Employee communication is a multidimensional construct and employees are not merely satisfied or dissatisfied with communication in general, they can express varying degrees of satisfaction about definite aspects of communication. The authors presented two particular components of communication: the content of organizational messages (as it concerns the members' satisfaction with what is being communicated) and the communication climate (how the information is communicated within an organization). The results of this research showed that the communication climate of a firm is more centrally linked to organizational identification than the content of the communication (Smidts et al., 2001, p. 1058). 
Leković B., Berber N.: The Relationship Between Communication Practice and...

\section{Research Methodology}

For the purpose of this study, the authors used data obtained during CRANET project (www.cranet.org) in the period 2008/2010. CRANET data and methodology were used in several HRM studies in the past related to performance management (Slavić, et al., 2014; Gurkov et al., 2012), compensation and benefits (McGraw, 2014; Štangl Šušnjar \&Slavić, 2012), training and development (McNamara et al., 2012; Leković \& Štangl Šušnjar, 2010), outsourcing (Reichel \& Lazarova, 2013; Štangl Šušnjar et al., 2013), industrial relation (Psychogios et al., 2014).

The European sample was created by the respondent companies from $20 \mathrm{EU}$ countries and five other European countries (Norway, Iceland, Russia, Serbia and Switzerland). The total number of organizations that participated in the research was 6415 in 32 countries, while in this study authors used only data for private firms, i.e. a total of 2871 organizations from 25 European countries, (table 1).

Table1. Sample of European countries with the number of participating organizations

\begin{tabular}{|l|c|c|c|c|}
\hline \multicolumn{1}{|c|}{ Country } & Frequency & Percent & $\begin{array}{c}\text { Valid } \\
\text { Percent }\end{array}$ & $\begin{array}{c}\text { Cumulative } \\
\text { Percent }\end{array}$ \\
\hline Austria & 117 & 4,1 & 4,1 & 4,1 \\
\hline Belgium & 191 & 6,7 & 6,7 & 10,7 \\
\hline Bulgaria & 170 & 5,9 & 5,9 & 16,6 \\
\hline Cyprus & 46 & 1,6 & 1,6 & 18,3 \\
\hline Denmark & 251 & 8,7 & 8,7 & 27,0 \\
\hline Estonia & 49 & 1,7 & 1,7 & 28,7 \\
\hline Finland & 46 & 1,6 & 1,6 & 30,3 \\
\hline France & 153 & 5,3 & 5,3 & 35,6 \\
\hline Germany & 343 & 11,9 & 11,9 & 47,6 \\
\hline Greece & 184 & 6,4 & 6,4 & 54,0 \\
\hline Hungary & 95 & 3,3 & 3,3 & 57,3 \\
\hline Ireland & 85 & 3,0 & 3,0 & 60,3 \\
\hline Italy & 137 & 4,8 & 4,8 & 65,0 \\
\hline Lithuania & 90 & 3,1 & 3,1 & 68,2 \\
\hline Netherlands & 66 & 2,3 & 2,3 & 70,5 \\
\hline Slovakia & 197 & 6,9 & 6,9 & 77,3 \\
\hline Slovenia & 137 & 4,8 & 4,8 & 82,1 \\
\hline Sweden & 159 & 5,5 & 5,5 & 87,6 \\
\hline United Kingdom & 93 & 3,2 & 3,2 & 90,9 \\
\hline Iceland & 67 & 2,3 & 2,3 & 93,2 \\
\hline Norway & 36 & 1,3 & 1,3 & 94,5 \\
\hline Russia & 49 & 1,7 & 1,7 & 96,2 \\
\hline Serbia & 32 & 1,1 & 1,1 & $\mathbf{1 0 0 , 0}$ \\
\hline Switzerland & 2,7 & 2,7 & $\mathbf{1 0 0 , 0}$ & \\
\hline Total & 100,0 & & \\
\hline
\end{tabular}

Source: Authors' analysis based on CRANET data 
Leković B., Berber N.: The Relationship Between Communication Practice and...

Total number of employees in observed organizations is 5775341, and the main sectors involved were metal manufacturing, mechanical, electrical and instrument engineering ( $17.4 \%$ of organizations), other manufacturing (16.2\%), banking; finance; insurance; business services (13.4\%) and retail and distribution; hotels; catering; repairs (11.8\%). According to mentioned researches in the past, available data and current views on the importance of the communication authors proposed next hypotheses:

H0: There are statistically significant differences between the level of organizational performances in companies with a formal communication about the organization of work, financial results and organizational strategy.

H1: Private firms in Europe usually perform direct "upward" communication and verbal communication the process of communication between managers and employees.

H2: Private firms in Europe that operate mainly on international market usually inform their employees about strategy, finances and organization of work more than companies that operate on local market.

The authors used several statistical techniques to explore variables. For the exploration of the upward and downward communication, and direct and indirect communication, we used descriptive techniques. In case of the exploration of differences between performances according to the level of the downward communication we used t-test of independent samples. We used chi square for examining the market orientation of the organizations and communication to employees. Regarding variables, the authors used the level of organizational performances (rate of innovation, productivity, profitability and service quality), communication techniques, level of direct and indirect communication, and upward and downward communication.

\section{Results of the analysis}

Study of the trend in the usage of communication techniques and upward and downward communications, as well as the identification of the level of direct and indirect communication is presented in table 2. Questions were asked in the form of Likert scale from 0 -not used at all to 4-used to a large extent. 
Leković B., Berber N.: The Relationship Between Communication Practice and...

Table 2. Upward communication

\begin{tabular}{|c|c|c|c|c|c|c|c|c|c|}
\hline 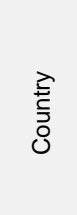 & 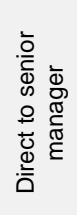 & 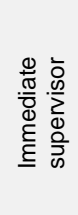 & 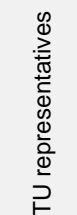 & $\begin{array}{l}\overline{\overline{0}} \\
\bar{c} \\
0 \\
0 \\
0 \\
\bar{y} \\
\bar{\vdots} \\
3\end{array}$ & 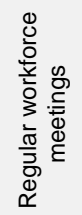 & 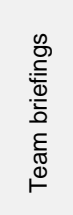 & 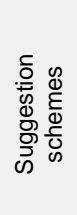 & 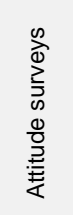 & 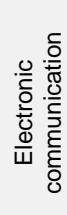 \\
\hline Total & 2,03 & 3,05 & 1,16 & 1,27 & 1,88 & 2,02 & 1,20 & 1,49 & 1,93 \\
\hline
\end{tabular}

Source: Authors' analysis based on CRANET data

From table 2 we can see that employees mostly use upward communication trough immediate supervisors (3.05). Very common way of communication is a direct communication to managers (2.03), trough team briefings (2.02) and electronic communication (1.93). Employees use trade union representatives less often (1.16). This is also confirmation of the presented thoughts about direct communication (without any representatives).

Table 3. Downward communication

\begin{tabular}{|c|c|c|c|c|c|}
\hline $\begin{array}{l}\text { D } \\
\text { 竞 } \\
\text { U }\end{array}$ & 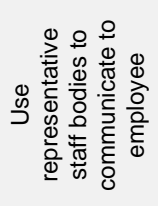 & 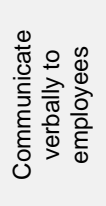 & 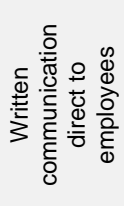 & 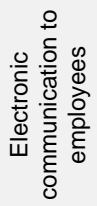 & 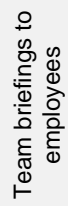 \\
\hline Total & 1,33 & 3,00 & 2,77 & 2,86 & 2,57 \\
\hline
\end{tabular}

Source: Authors' analysis based on CRANET data

From table 3 we can see that managers mostly use downward communication trough verbal communication (3.00). Very common way of communication is a direct communication with employees through electronic media (2.86), written communication to employees (2.77) and team briefings (2.57). Managers use trade union representatives less often (1.33). This also confirms the presented thoughts about direct communication. The findings are in the line with the research of Buciuniene and Kazlauskaite (2012) where they found that the greatest extent of the means of communication to employees comprises verbal and electronic communication, while the upward communication is done through immediate supervisors in most Lithuanian companies.

Figure 1 presents the level of communication about important information on strategy, financial performance and organization of work in private 
Leković B., Berber N.: The Relationship Between Communication Practice and...

organizations in Europe. It is obvious that almost 95\% of organizations inform their managers about business strategy and financial performances, while 91\% of examined organizations claimed that they inform their managers about organization of work. Professional, clerical and manual workers are informed less about strategy and financial performances and more about organization of work.

Figure 1. Communication about strategy, financial performance and organization of work

\begin{tabular}{|c|c|c|c|c|}
\hline \\
\hline \multirow{3}{*}{$\begin{array}{l}90,0 \% \\
80,0 \%\end{array}$} & $94,9 \%$ & $94,8 \%$ & $91,1 \%$ & \multirow{7}{*}{$\begin{array}{l}\text { Professionals } \\
\Delta \text { Clericals } \\
\times \text { Manuals } \\
\\
\text { Managers }\end{array}$} \\
\hline & & & $80,9 \%$ & \\
\hline & & & $78,7 \%$ & \\
\hline \multirow{3}{*}{$\begin{array}{l}70,0 \% \\
60,0 \% \\
50,0 \%\end{array}$} & $69,4 \%$ & $71,0 \%$ & & \\
\hline & $59,4 \%$ & $\Delta 63,5 \%$ & $\times 63,0 \%$ & \\
\hline & $\times 423 \%$ & $\times 45,8 \%$ & & \\
\hline $\begin{array}{l}40,0 \% \\
30,0 \%\end{array}$ & & & & \\
\hline \multirow{2}{*}{$20,0 \%$} & & & & \\
\hline & & & & \\
\hline $10,0 \%$ & Strategy & Financial performance & \multicolumn{2}{|c|}{ Organization of work } \\
\hline
\end{tabular}

Source: Authors' analysis based on CRANET data

For the exploration of the hypothesis about internalization of business, the authors used information about strategy, financial performances and organization of work for managers, professionals, clericals and manuals and orientation on global or local market to find out the differences between organizations.

From table 4 we can conclude that if organizations are oriented more to the international market then larger percentage of organizations inform their employees about strategic, financial and organizational issues. According to the chi square test, these differences are statistically significant, proved by $\mathrm{X} 2$ and $p$ value in the table. If the $p$ value is lower than 0.05 , differences are significant. These findings are important in terms of many challenges that companies, working on international market, are faced with. Mainly, there are cultural values and social issues that are different in each country. Therefore effective communication is particularly important in terms of reconciliation of those differences. National culture, as a sum of beliefs, norms and ideas which results in the specific behavior of people, influences organizational culture of each organization. Successful and effective communication is crucial for business processes in terms of understanding and solving all possible problems that occur as a result of cultural differences. 
Leković B., Berber N.: The Relationship Between Communication Practice and...

Table 4. Differences between market orientation regarding briefing about strategy, financial performances and organization of work

\begin{tabular}{|c|c|c|c|c|c|c|c|}
\hline & & \multicolumn{2}{|c|}{$\begin{array}{l}\text { Management formally } \\
\text { briefed about business } \\
\text { strategy }\end{array}$} & \multirow[t]{2}{*}{ Chi square } & \multicolumn{2}{|c|}{$\begin{array}{c}\text { Professional formally } \\
\text { briefed about business } \\
\text { strategy }\end{array}$} & \multirow[t]{2}{*}{ Chi square } \\
\hline & & No & Yes & & No & Yes & \\
\hline \multirow{2}{*}{$\begin{array}{l}\text { Main } \\
\text { market }\end{array}$} & Local & $6,4 \%$ & $93,6 \%$ & $X^{2}=11,048$ & $33,0 \%$ & $67,0 \%$ & $x^{2}=6,424$ \\
\hline & International & $3,6 \%$ & $96,4 \%$ & $p=0,001$ & $28,4 \%$ & $71,6 \%$ & $p=0,011$ \\
\hline & & \multicolumn{2}{|c|}{$\begin{array}{l}\text { Management formally } \\
\text { briefed about financial } \\
\text { performance }\end{array}$} & \multirow[t]{2}{*}{ Chi square } & \multicolumn{2}{|c|}{$\begin{array}{l}\text { Professional formally } \\
\text { briefed about financial } \\
\text { performance }\end{array}$} & Chi square \\
\hline & & No & Yes & & No & Yes & \\
\hline \multirow{2}{*}{$\begin{array}{l}\text { Main } \\
\text { market }\end{array}$} & Local & $6,5 \%$ & $93,5 \%$ & $X^{2}=10,330$ & $32,9 \%$ & $67,1 \%$ & $X^{2}=18,220$ \\
\hline & International & $3,8 \%$ & $96,2 \%$ & $p=0,001$ & $25,4 \%$ & $74,6 \%$ & $\mathrm{p}=0,00$ \\
\hline & & \multicolumn{2}{|c|}{$\begin{array}{c}\text { Management formally } \\
\text { briefed about } \\
\text { organization of work }\end{array}$} & \multirow[t]{2}{*}{ Chi square } & \multicolumn{2}{|c|}{$\begin{array}{l}\text { Professional formally } \\
\text { briefed about } \\
\text { organization of work }\end{array}$} & Chi square \\
\hline & & No & Yes & & No & Yes & \\
\hline \multirow{2}{*}{$\begin{array}{l}\text { Main } \\
\text { market }\end{array}$} & Local & $8,9 \%$ & $91,1 \%$ & $x^{2}=0,435$ & $20,0 \%$ & $80,0 \%$ & $x^{2}=2,039$ \\
\hline & International & $8,2 \%$ & $91,8 \%$ & $p=0,510$ & $17,9 \%$ & $82,1 \%$ & $p=0,153$ \\
\hline & & \multicolumn{2}{|c|}{$\begin{array}{l}\text { Clerical formally briefed } \\
\text { about business strategy }\end{array}$} & \multirow[t]{2}{*}{ Chi square } & \multicolumn{2}{|c|}{$\begin{array}{l}\text { Manual formally briefed } \\
\text { about business strategy }\end{array}$} & Chi square \\
\hline & & No & Yes & & No & Yes & \\
\hline \multirow{2}{*}{$\begin{array}{l}\text { Main } \\
\text { market }\end{array}$} & Local & $43,9 \%$ & $56,1 \%$ & $X^{2}=11,825$ & $61,3 \%$ & $38,7 \%$ & $x^{2}=11,610$ \\
\hline & International & $37,3 \%$ & $62,7 \%$ & $p=0,001$ & $54,4 \%$ & $45,6 \%$ & $p=0,001$ \\
\hline & & \multicolumn{2}{|c|}{$\begin{array}{l}\text { Clerical formally briefed } \\
\text { about financial } \\
\text { performance }\end{array}$} & \multirow[t]{2}{*}{ Chi square } & \multicolumn{2}{|c|}{$\begin{array}{l}\text { Manual formally briefed } \\
\text { about financial } \\
\text { performance }\end{array}$} & Chi square \\
\hline & & No & Yes & & No & Yes & \\
\hline \multirow{2}{*}{$\begin{array}{l}\text { Main } \\
\text { market }\end{array}$} & Local & $41,6 \%$ & $58,4 \%$ & $X^{2}=26,077$ & $60,4 \%$ & $39,6 \%$ & $X^{2}=32,759$ \\
\hline & International & $31,9 \%$ & $68,1 \%$ & $p=0,00$ & $48,7 \%$ & $51,3 \%$ & $p=0,000$ \\
\hline & & \multicolumn{2}{|c|}{$\begin{array}{c}\text { Clerical formally briefed } \\
\text { about organization of } \\
\text { work }\end{array}$} & \multirow[t]{2}{*}{ Chi square } & \multicolumn{2}{|c|}{$\begin{array}{l}\text { Manual formally briefed } \\
\text { about organization of } \\
\text { work }\end{array}$} & Chi square \\
\hline & & No & Yes & & No & Yes & \\
\hline \multirow{2}{*}{$\begin{array}{l}\text { Main } \\
\text { market }\end{array}$} & Local & $21,3 \%$ & $78,7 \%$ & $X^{2}=0,066$ & $39,6 \%$ & $60,4 \%$ & $x^{2}=6,730$ \\
\hline & International & $20,9 \%$ & $79,1 \%$ & $p=0,798$ & $34,6 \%$ & $65,4 \%$ & $p=0,009$ \\
\hline
\end{tabular}

Source: Authors' analysis based on CRANET data

Beside culture, as a very important factor that influences the whole process of business, and especially HRM activities (Berber, 2013), there are different legal regimes where laws in relation to the business of enterprises, workforce and tax systems are of a great importance. Clear and unambiguous information are important for the compliance with the different legal norms and the success of business operations on foreign markets. Economic challenges 
Leković B., Berber N.: The Relationship Between Communication Practice and...

are also important. Different economic systems needs very sophisticated business policy, especially business straegies that will ensure successful satisfaction of all business goals. Having in mind mentioned groups of challenges, it is clear that information about strategies, results and work organization are one of the preconditions for success on international market. Thus, according to the results in table 4, organizations working on foreign markets use communication in greater extent than organizations that work only on local market.

At the end of the analysis the authors explored differences between formal briefings of managers about important issues regarding the level of performances.

Table 5. T-test for the exploration of differences between formal briefings of managers and level of performances

\begin{tabular}{|c|c|c|c|c|}
\hline Performance measures & $\begin{array}{l}\text { Management formally briefed } \\
\text { about business strategy }\end{array}$ & Mean & Std. Deviation & $\begin{array}{l}\text { Sig. (2- } \\
\text { tailed) }\end{array}$ \\
\hline \multirow{2}{*}{ Rating of service quality } & No & 3,75 & ,798 & \multirow{2}{*}{0.025} \\
\hline & Yes & 3,92 & ,756 & \\
\hline \multirow{2}{*}{ Rating of level of productivity } & No & 3,43 & ,879 & \multirow{2}{*}{0.007} \\
\hline & Yes & 3,64 & ,817 & \\
\hline \multirow{2}{*}{ Rating of profitability } & No & 3,34 & 1,018 & \multirow{2}{*}{0.121} \\
\hline & Yes & 3,48 & ,913 & \\
\hline \multirow{3}{*}{ Rating of rate of innovation } & No & 3,12 & 1,089 & \multirow{2}{*}{0.000} \\
\hline & Yes & 3,49 & ,943 & \\
\hline & $\begin{array}{l}\text { Management formally briefed } \\
\text { about financial performance }\end{array}$ & Mean & Std. Deviation & $\begin{array}{l}\text { Sig. (2- } \\
\text { tailed) }\end{array}$ \\
\hline \multirow{2}{*}{ Rating of service quality } & No & 3,85 & ,850 & \multirow{2}{*}{0.349} \\
\hline & Yes & 3,92 & ,754 & \\
\hline \multirow{2}{*}{ Rating of level of productivity } & No & 3,55 & ,892 & \multirow{2}{*}{0.292} \\
\hline & Yes & 3,63 & ,816 & \\
\hline \multirow{2}{*}{ Rating of profitability } & No & 3,12 & 1,006 & \multirow{2}{*}{0.000} \\
\hline & Yes & 3,48 & ,913 & \\
\hline \multirow{3}{*}{ Rating of rate of innovation } & No & 3,19 & 1,117 & \multirow{2}{*}{0.005} \\
\hline & Yes & 3,49 & ,943 & \\
\hline & $\begin{array}{l}\text { Management formally briefed } \\
\text { about organization of work }\end{array}$ & Mean & Std. Deviation & $\begin{array}{l}\text { Sig. (2- } \\
\text { tailed) }\end{array}$ \\
\hline \multirow{2}{*}{ Rating of service quality } & No & 3,89 & ,872 & \multirow{2}{*}{0.650} \\
\hline & Yes & 3,92 & ,748 & \\
\hline \multirow{2}{*}{ Rating of level of productivity } & No & 3,63 & ,899 & \multirow{2}{*}{0.970} \\
\hline & Yes & 3,62 & ,814 & \\
\hline \multirow{2}{*}{ Rating of profitability } & No & 3,47 & ,963 & \multirow{2}{*}{0.942} \\
\hline & Yes & 3,47 & ,916 & \\
\hline \multirow{2}{*}{ Rating of rate of innovation } & No & 3,36 & 1,021 & \multirow{2}{*}{0.052} \\
\hline & Yes & 3,49 & ,946 & \\
\hline
\end{tabular}

Source: Authors' analysis based on CRANET data 
Leković B., Berber N.: The Relationship Between Communication Practice and...

In table 5 there have been presented, in a simplified way, t-test that was used to observe differences between ratings of performances regarding existence (yes or no) formal briefing of managers about strategy, financial performances and organization of work. From table it is obvious that there are statistically significant differences $(p<0.05)$ between organizations that inform mangers and those that don't inform their managers. Companies that inform their managers about strategic and financial issues have higher ratings of all performance measures (service quality, productivity, profitability and the rate of innovation). In case of information about organization of work authors did not find any significant difference. These findings are interesting in terms of managers' responsibilities for the success of business. Usually, managers have the largest part of responsibilities for the accomplishment of goals and business results. Organization of work, especially daily tasks, is commonly delegated to the lower level of management and workers. According to the results, significant differences exist in case when managers are formally informed about strategic and financial information. Having all the information that are important for decision making process and directing of a business, managers are able to perform in a way of enabling organizations to reach better performances, in this case, productivity, profitability, quality and innovativeness. Communication about strategic issues does not only imply providing information, but also involving, engaging managers and workers in business processes of a company. According to the data from table 5, companies, where managers are informed about strategy and financial results, information vital for the business, achieve higher level of performances. On the other hand, in case of information about organization of work there are differences, companies that inform their managers about these issues gain higher levels of organizational performances, but these differences are not statistically significant. It is important to emphasize that the authors examined only differences in performances in relation to the communication about several issues. Results showed that communication is important for organizations and their functioning, but it is not the only factor that influences organizational performances.

\section{Conclusion}

In the research performed in this paper the authors examined three hypotheses. Hypothesis $\mathrm{HO}$ was partially proved since organizations that inform their managers about strategic and financial issues have higher ratings of all performance measures (service quality, productivity, profitability and rate of innovation). In case of information about organization of work, the authors did not find any significant difference. While the HO hypothesis was not fully proved, hypothesis $\mathrm{H} 2$ was confirmed, meaning that organizations oriented to the international market, in larger percentage inform their employees about 
Leković B., Berber N.: The Relationship Between Communication Practice and...

strategic, financial and organizational issues. Finally, the authors explored trends in the usage of upward and downward communication. Hypothesis $\mathrm{H} 1$ was proved since communication techniques like direct verbal and direct communication to immediate supervisors are used in a greater extent than others. Our findings are in the line with the presented theoretical literature, especially regarding the usage of direct communication instead of indirect.

To conclude, contemporary organizations should pay more attention to communication policy since there are evidences of its positive impact on organization's effectiveness. Managers should in particular foster direct communication with their employees about all important issues and facts, since direct communication was found as one of the most frequently used.

\section{References}

Berber, N. (2013). The influence of culture on human resource management: Compensations and benefits. Anali Ekonomskog fakulteta u Subotici, 49(29), 105-117.

Brewster, C., Sparrow, P. \& Vernon, G. (2007). International Human Resource Management. London: Chartered Institute of Personnel and Development.

Brown, A., Forde, C., Spencer, D., \& Charlwood, A. (2008). Changes in HRM and job satisfaction, 1998-2004: evidence from the Workplace Employment Relations Survey. Human Resource Management Journal, 18(3), 237-256.

Buciuniene, I., \& Kazlauskaite, R. (2012). The linkage between HRM, CSR and performance outcomes. Baltic Journal of Management, 7(1), 5-24.

Croucher, R., Gooderham, P., \& Parry, E. (2006). The influences on direct communication in British and Danish firms: Country, 'strategic HRM' or unionization?. European Journal of Industrial Relations, 12(3), 267-286.

Damnjanović, P., Suša, B., Skunca, D., Milenković, S. \& Ristić, Đ. (2012). Menadžment ljudskih resursa. Beograd: Etnostil.

Den Hartog, D. N., Boon, C., Verburg, R. M., \& Croon, M. A. (2013). HRM, Communication, Satisfaction, and Perceived Performance: A Cross-Level Test. Journal of Management, 39(6), 1637-1665.

Gurkov, I., Zelenova, O., \& Saidov, Z. (2012). Mutation of HRM practices in Russia: an application of CRANET methodology. The International Journal of Human Resource Management, 23(7), 1289-1302.

Leković, B. (2011). Principi menadžmenta. Bečej: Proleter.

Leković, B., \& Štangl Šušnjar, G. (2010). Obuka i razvoj karijere u komparativnom menadžmentu ljudskih resursa zemalja istočne Evrope. Anali Ekonomskog fakulteta u Subotici, (23), 23-35.

McGraw, P. (2014). Changing patterns of compensation and benefits in multinational and Australian companies 1996-2009. Asia Pacific Journal of Human Resources.

Poór, J., Farkas, F., \& Engle, A.D. (2012). Human Resource Management Issues and Challenges in Foreign Owned Companies: Central and Eastern Europe. Komárno, Slovakia: Janos Selye University. 
Leković B., Berber N.: The Relationship Between Communication Practice and...

Poor, J., Nikolić, M., Slavić, A., \& Štangl - Šušnjar, G. (2012). HRM under Changes at Foreign Subsidiaries in Serbia in Line With a Central and Eastern European Survey. Strategic Management, 17(1), 42-52.

Psychogios, A., Brewster, C., Missopoulos, F., Kohont, A., Vatchkova, E., \& Slavic, A. (2014). Industrial relations in South-Eastern Europe: disaggregating the contexts. The International Journal of Human Resource Management, 25(11), 1592-1612.

Reichel, A., \& Lazarova, M. (2013). The Effects of Outsourcing and Devolvement on the Strategic Position of HR Departments. Human Resource Management, 52(6), 923-946.

Slavić, A., Berber, N., \& Leković, B. (2014). Performance management in international human resource management. Serbian Journal of Management, 9(1), 45-58.

Smidts, A., Pruyn, A. T. H., \& Van Riel, C. B. (2001). The impact of employee communication and perceived external prestige on organizational identification. Academy of Management Journal, 44(5), 1051-1062.

Štangl Šušnjar, G., \& Slavić, A. (2012). Changes in the human resource compensation systems of European companies: Based on the CRANET research result analysis. Strategic Management, 17(4), 32-40.

Tanova, C., \& Nadiri, H. (2010). The role of cultural context in direct communication. Baltic Journal of Management, 5(2), 185-196.

Vemić-Đurković, J., Jotić, J., \& Marić, R. (2013). Uporedna analiza doprinosa upravljanja ljudskim resursima organizacionim performansama banaka u Srbiji. Industrija, 41(4), 91-107. 